\title{
Optimasi Portofolio Resiko Menggunakan Model Markowitz MVO Dikaitkan Dengan Keterbatasan Manusia Dalam Memprediksi Masa Depan Dalam Perspektif Al-Qur’an
}

\author{
Noor Saif Muhammad Mussafi \\ Program Studi Matematika, Fakultas Sains dan Teknologi, UIN Sunan Kalijaga, JI. Marsda Adisucipto \\ No. 1 Yogyakarta, Indonesia \\ Korespondensi; Email: noor.saif@uin-suka.ac.id
}

\begin{abstract}
Abstrak
Risiko Portofolio keuangan modern telah menjadi semakin teknis, membutuhkan penggunaan alat matematika yang canggih baik dalam penelitian maupun praktik. Karena perusahaan tidak dapat memastikan diri sepenuhnya terhadap risiko, karena ketidakmampuan manusia dalam memprediksi masa depan tepatnya yang ditulis dalam alQuran surah Luqman ayat 34, mereka harus mengelolanya untuk menghasilkan portofolio yang optimal. Tujuannya di sini adalah untuk meminimalkan varians di antara semua portofolio, atau alternatifnya, untuk memaksimalkan hasil yang diharapkan di antara semua portofolio yang setidaknya memiliki perkiraan pengembalian yang diharapkan. Selanjutnya, penelitian ini berfokus pada optimalisasi portofolio risiko yang disebut Markowitz MVO (Mean-Variance Optimization). Beberapa kerangka teoritis untuk analisis adalah mean aritmetika, mean geometrik, varians, kovarian, pemrograman linier, dan pemrograman kuadratik. Selain itu, menemukan portofolio varian minimum menghasilkan pemrograman kuadran cembung, yaitu meminimalkan fungsi objektif $\frac{1}{2} x^{T} Q$ dengan batasan $\mu^{T} x \geq R$ dan $A=b$. Hasil dari penelitian ini adalah solusi portofolio risiko yang optimal dalam beberapa investasi yang dapat diselesaikan dengan lancar menggunakan perangkat lunak MATLAB R2007b bersamaan dengan analisis grafisnya.
\end{abstract}

Kata Kunci: Pemrograman Kuadrat; Risiko Portofolio Optimal; Expected Return; Markowitz MVO

\begin{abstract}
Risk portfolio on modern finance has become increasingly technical, requiring the use of sophisticated mathematical tools in both research and practice. Since companies cannot insure themselves completely against risk, as human incompetence in predicting the future precisely that written in Al-Quran surah Luqman verse 34, they have to manage it to yield an optimal portfolio. The objective here is to minimize the variance among all portfolios, or alternatively, to maximize expected return among all portfolios that has at least a certain expected return. Furthermore, this study focuses on optimizing risk portfolio so called Markowitz MVO (Mean-Variance Optimization). Some theoretical frameworks for analysis are arithmetic mean, geometric mean, variance, covariance, linear programming, and quadratic programming. Moreover, finding a minimum variance portfolio produces a convex quadratic programming, that is minimizing the objective function $\frac{1}{2} x^{T} Q$ with constraints $\mu^{T} x \geq$ $R$ and $A=b$. The outcome of this research is the solution of optimal risk portofolio in some investments that could be finished smoothly using MATLAB R2007b software together with its graphic analysis.
\end{abstract}

Keywords: Q uadratic Programming; O ptimal Risk Portofolio; Expected Return; Markowitz MVO

\section{Pendahuluan}

Manajemen resiko merupakan salah satu unsur penting dalam kegiatan ekonomi, khususnya bidang keuangan, suatukeputusan yang dibuat pada hari ini mempengaruhi peristiwa yang terjadi di masa 
mendatang. Allah SWT juga memberikan informasi yang cukup jelas terkait masa depan dalam AlQuran Surat Luqman ayat 34:

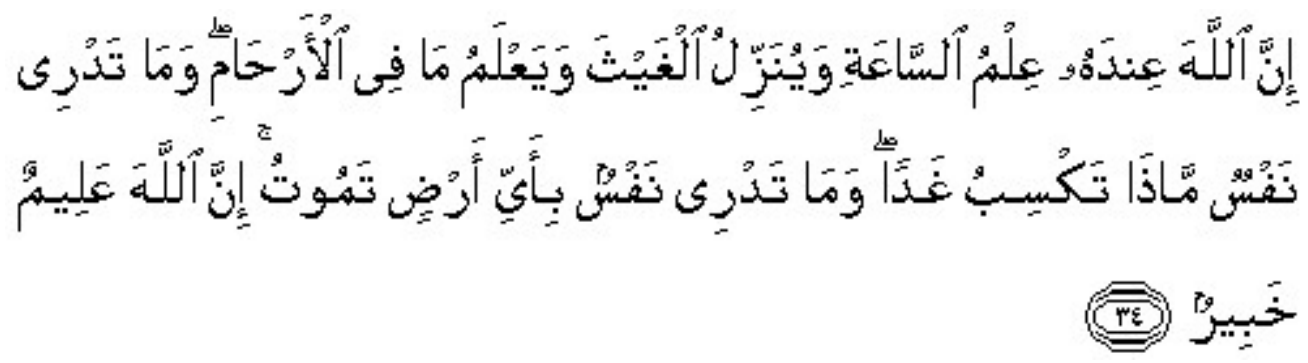

Artinya: Sesungguhnya Allah, hanya pada sisi-Nya sajalah pengetahuan tentang Hari Kiamat; dan Dialah Yang menurunkan hujan, dan mengetahui apa yang ada dalam rahim. Dan tiada seorangpun yang dapat mengetahui (dengan pasti) apa yang akan diusahakannya besok. Dan tiada seorangpun yang dapat mengetahui di bumi mana dia akan mati. Sesungguhnya Allah Maha Mengetahui lagi Maha Mengenal .

Secara garis besar ayat ini menunjukkan bahwamanusia diberikan motivasi dan kesempatanyang seluas-luasnya untuk berikhtiar meraih yang terbaik di kemudian harisekalipun mereka tidak dapat mengetahui tentang apa yang akan dialaminya termasuk diantaranya resiko yang harus dihadapinya. Namun demikian, dengan dasar ilmu manusia diperbolehkan untuk memprediksi sesuatu yang terjadi di masa mendatang.

Di samping itu, perusahaan-perusahaan selalu dihadapkan dengan resiko, maka kemampuan manajerial di bidang resiko menjadi mutlak diperlukan. Adapun manajemen resiko pada dunia perbankan berkaitan dengan manajemen proses dan pemodelan yang akan diimplementasikan dalam pengambilan kebijakan terkait resiko. Manajemen proses dan pemodelan mencakup teknik dan alatalat manajemen yang diperlukan untuk mengukur, memonitor, dan mengontrol segala macam resiko seperti resiko kredit, resiko investasi, resiko pasar, resiko suku bunga, resiko likuiditas, dan resiko operasional [3]. Beberapacontoh perhitungan resiko portofolio bank adalah Markowitz MVO (MeanVariance Optimization), Value-at-Risk (VaR), dan Conditional Value-at-Risk (CVaR). Dalam makalah ini, penulis menfokuskan pada deskripsi Markowitz MVOdalam mengoptimalkan portofolio resiko. Markowitz (1959) mengatakan bahwa proses seleksi portofolio berkaitan dengan kepercayaan investor tentang investasi di masa mendatang dengan didasarkan pada expected return dan variance namun belum menggunakan prinsip program kuadrat. Tujuan dari penulisan ini adalah memberikan alternatif solusi dalam memilih portofolio optimal (returnterbaik) menggunakan program kuadrat kepada para investor dalam mengelola modalnya untuk berinvestasi.

\section{Optimisasi}

Optimisasi secara matematis berarti meminimalkan atau memaksimalkan fungsi tujuan dari beberapa variabel keputusan dengan kendala tertentu. Permasalahan optimisasi dalam penulisan ini dibatasi pada optimisasi diskrit dengan batasan tertentu (constrained optimization).

Missal diketahui suatu fungsi $f(x): \mathbb{R}^{n} \rightarrow \mathbb{R}$ dan suatu himpunan $S \subseteq \mathbb{R}^{n}$. Masalah pencarian suatu $x^{*} \in \mathbb{R}^{n}$ yang memenuhi

$$
\begin{aligned}
& m \quad{ }_{x} f(x) \\
& \text { s. s. } x \in S
\end{aligned}
$$

Disebut masalah optimisasi (MO). Fungsi $f$ menyatakan fungsi tujuan dan $S$ adalah daerah yang mungkin. Permasalahannya adalah menentukan solusi $x^{*} \in S$ sedemikian sehingga memenuhi pertidaksamaan berikut

$$
f\left(x^{*}\right) \leq f(x)
$$


Salah satu bagian dasar dalam MO adalah program linear (/inear programming). Program linear (PL) merupakan masalah meminimalkan atau memaksimalkan fungsi tujuan linear dengan batasan persamaan linear dan pertidaksamaan linear. Secara sederhana, program linear merupakan MO (1) pada kasus semua fungsinya linear, yaitu

$$
\begin{gathered}
m{ }_{x} c^{T} x \\
\text { s.s. } A=b \\
x \geq 0
\end{gathered}
$$

Matriks $A \in \mathbb{R}^{m}$ dengan vektor $b \in \mathbb{R}^{m}$ dan $c \in \mathbb{R}^{n}$ diketahui. Adapun solusi yang dicari adalah vector $x \in \mathbb{R}^{n}$ dengan koefisien non-negatif dan memenuhi persamaan linear

$$
\begin{gathered}
a_{1} x_{1}+\cdots+a_{1 n} x_{n} \leq b_{1} \\
a_{2} x_{1}+\cdots+a_{2 n} x_{n} \leq b_{2} \\
\vdots \\
a_{m 1} x_{1}+\cdots+a_{m} x_{n} \leq b_{m}
\end{gathered}
$$

Tujuan akhir (2) adalah meminimalkan koefisien vektor $x$ pada fungsi tujuan $c^{T} x$ yaitu perkalian Scalar

$$
c^{T} x=\sum_{j=1}^{n} c_{j} x_{j}=c_{1} x_{1} \cdots+c_{n} x_{n}
$$

Pengembangan lebih lanjut dari program linear adalah masalah optimisasi dengan fungsi tujuan kuadrat yaitu program kuadrat (quadratic programming). Program kuadrat (PK) memungkinkan memiliki satu atau lebih kendala dalam bentuk persamaan ataupun pertidaksamaan. Bentuk umum dari program kuadrat adalah

$$
\begin{gathered}
m \quad x \frac{1}{2} x^{T} Q+c^{T} x \\
\text { s. S. } A=b \\
C \geq d \\
x \geq 0
\end{gathered}
$$

Matriks $A, C \in \mathbb{R}^{m} \quad$ dan tiga vektor $b \in \mathbb{R}^{m}, d \in \mathbb{R}^{m}$ dan $c \in \mathbb{R}^{n}$ diketahui. Adapun $Q$ merupakan matriks simetris $\left(Q_{i}=Q_{j}\right)$ karena $x^{T} Q=\frac{1}{2} x^{T}\left(Q+Q^{T}\right) x$. Tujuan akhir (3) adalah meminimalkan koefisien vektor $x$ pada fungsi tujuan kuadrat $\frac{1}{2} x^{T} Q+c^{T} x$.

\section{Portofolio Optimal}

Teori pemilihan portofolio optimal pertamakali diperkenalkan oleh Markowitz. Berikut ini adalah pemikiran Markowitz tentang deskripsi model dan hal-hal yang terkait dengan program kuadrat pada Portofolio optimal.

Misalkan seorang investor memiliki sejumlah dana yang akan diinvestasikan dalam surat-surat berharga (saham, obligasi, pasar uang, dan lain sebagainya) dengan laba acak. Untuk setiap surat berharga $i=1, \ldots, n$, misalkan expected return $\mu_{i}$ dan variance $\sigma_{i}^{2}$ diketahui. Selanjutnya untuk sebarang dua surat berharga $i$ dan $j$, koefisien korelasi $\rho_{i}$ juga diketahui. Jika proporsi dana yang diinvestasikan pada surat berharga $i$ direpresentasikan $x_{i}$, maka kita dapat menghitung expected return dan variance dari hasil portofolio $x=\left(x_{1}, x_{2}, \cdots, x_{n}\right)$ sebagai berikut. 
Dan

$$
E[x]=x_{1} \mu_{1}+x_{2} \mu_{2}+\cdots+x_{n} \mu_{n}=\mu^{T} x
$$

$$
V \quad[x]=\sum_{i, j} \rho_{i} \sigma_{i} \sigma_{j} x_{i} x_{j}=x^{T} Q
$$

Dengan $\rho_{i}=1, Q_{i}=\rho_{i} \sigma_{i} \sigma_{j}$ dan $\mu=\left(\mu_{1}, \cdots, \mu_{n}\right)$.

Portofolio vektor $x$ harus memenuhi $\sum_{i} x_{i}=1$. Portofolio feasiblex disebut efisien jika mampumenghasilkan expected return maksimum diantara portofolio-portofolio lainnya dengan varianceminimum. Koleksi portofolio optimal kemudian membentuk batas efisien (efficient frontier).

Masalah optimisasi portofolio Markowitz MVO dapat diformulasikan sebagai penentuan varianceportofolio minimum pada surat berharga hingga $n$ yang menghasilkan sekurang-kurangnya sebuah nilai tujuan dari expected return $R$. Secara matematis formulasi tersebut merefleksikan masalahprogram kuadrat.

$$
\begin{gathered}
\min _{x} x^{T} Q \\
\text { s. } s . e^{T} x=1 \\
\mu^{T} x \geq R \\
x \geq 0
\end{gathered}
$$

\section{Optimisasi Portofolio pada MATLAB}

Saat ini permasalahan optimisasi tidak hanya dapat diselesaikan secara manual namun juga dapat diselesaikan menggunakan bantuan beberapa software, salah satunya adalah MATLAB. Portofolio optimal Markowitz MVO pada prinsipnya menggunakan model program kuadrat, yaitu meminimalkan fungsi kuadrat terhadap satu atau lebih fungsi kendala dalam bentuk persamaan ataupun pertidaksamaan.

Dalam optimization toolbox MATLAB, salah satu sintak yang dapat digunakan dalam menyelesaikan program kuadrat yaitu

$$
x=q \quad(Q, c, A, b, A \quad, b \quad)
$$

dengan $Q, A$, dan Aeq adalah matriks sedangkan $c, b$, dan beq merupakan vektor. Sedangkan sintak $x=q \quad(Q, c, A, b, A, b)$ berarti vektor $x$ meminimalkan fungsi kuadrat $\frac{1}{2} x^{T} Q+c^{T} x$ terhadap dua fungsi kendala yaitu pertidaksamaan $A \leq b$ dan persamaan

$$
A . x=b
$$

Di samping itu, financial toolbox pada MATLAB menyediakan fungsi frontcon untuk menganalisa MeanVariance efisien, yaitu menghitung suatu portofolio investasi sedemikian sehingga meminimumkan resiko untuk beberapa prediksi return yang diketahui. Fungsi frontcon memerlukan input vector ExpRet (rataan expected return tiapaset) dan matriks CovMat (matriks kovarians). Dengan dua input tersebut, kita dapat membuat grafik dua dimensi berupa kurva batas efisien (efficient frontier) yang menghasilkan resiko (simpangan baku) sebagai koordinat $x$, expected return sebagai koordinat $y$, dan beban tiap aset. Sintak fungsi frontcon yang dimaksud dideskripsikan sebagai berikut [5]:

$$
\begin{aligned}
& E \quad=[\cdots] \\
& C \quad=[\cdots] \\
& {[P \quad P \quad, P \quad]=f \quad[E \quad, C \quad, 10]} \\
& f \quad[E \quad, C \quad, 10]
\end{aligned}
$$


dengan PRisk merepresentasikan resiko (simpangan baku), PRoR menyatakan expected return, dan PWts menyatakan beban yang dialokasikan pada tiap aset. Jumlah semua beban pada portofolio selalu sama dengan 1 (lihat kendala pertama pada (4)).

\section{Hasil dan Pembahasan}

Pada bagian sebelumnya telah dijelaskan bahwa program kuadrat merupakan permasalahan meminimalkan fungsi tujuan kuadrat terhadap kendala yang berbentuk persamaan linear dan pertidaksamaan linear. Masalah program kuadrat banyak digunakan dalam pemodelan optimisasi, salah satunya MVO yang bertujuan memilih portofolio surat-surat berharga (aset) agar diperoleh portofolio efisien yaitu expected return maksimum dan resiko (variance) minimum [1].

Kumpulan portofolio efisien tersebut akan membentuk batas efisien (efficient frontier) dari seluruh portofolio. Batas efisien selanjutnya dapat direpresentasikan dalam grafik dua dimensi dimana tiap koordinatnya berkesesuaian dengan expected return dan simpangan baku.

Misalkan $Q$ adalah positive definite yaitu $x^{T} Q x>0$, sehingga ada portofolio unik pada $x$ yang memiliki variance minimum. Misal portofolio tersebut dinotasikan $x_{\min }$ dengan expected return $\mu^{T} x_{\min }$ dengan interval $R_{\min }$ dan $R_{\max }$. Dalam hal ini $x_{\min }$ merupakan portofolio efisien. Mengacu pada notasi di atas, masalah Markowitz MVO adalah penentuan variance portofolio minimum pada surat berharga $1, \ldots, \mathrm{n}$ yang menghasilkan sekurang-kurangnya sebuah nilai tujuan dari expected return (misalkan $b$ ). Secara matematis formula tersebut menghasilkan masalah program kuadrat

$$
\begin{gathered}
m \quad x \frac{1}{2} x^{T} Q+c^{T} x \\
\text { s.s. } \mu^{T} x \geq R \\
A=b \\
C \geq d
\end{gathered}
$$

Kendala pertama pada (5) menunjukkan bahwa expected return tidak boleh kurang dari nilai tujuan $R$. Masalah (5) dapat diselesaikan dengan mengasumsikan interval $R$ antara $R_{\min }$ dan $R_{\max }$ sehingga diperoleh seluruh portofolio efisien yang diharapkan. Konstanta $\frac{1}{2}$ pada fungsi tujuan hanya erupakan setengah variance total portofolio dan tidak berpengaruh pada penentuan solusi optimal.

Berikut diketahui suatu data portofolio saham, obligasi, dan dana tunai Amerika Serikat yang merupakan review keuntungan tiga aset pada periode antara 1960 dan 2003 (lihat tabel 1). Dari data tersebut selanjutnya akan dicari portofolio resiko optimal masing-masing variabel yaitu saham, obligasi, dan danatunai. Data yang dimaksud adalah sebagai beikut:

1. Keuntungan saham yang diperoleh dari indeks Standard and Poor's 500 (saham 500 perusahaan dengan modal besar).

2. Keuntungan obligasi diperoleh dari indeks negosiasi hutang kupon obligasi Amerika Serikat.

3. Dana tunai yang dimaksud adalah dana yang diinvestasikan pada pasar uang.

Misalkan $l_{\text {it }}$ adalah total return pada tabel 1 untuk aset $i=1,2,3$ dan $t=0, . ., T$ dimana $t=0$ berkesesuaian dengan 1960 dan $t=T$ dengan 2003. Setiap aset $i$ pada data mentah $l_{i t}, t=0, .$. , Dapat dikonversi menjadi rate of return $r_{i t}, t=0, . ., T$ menggunakan formula berikut:

$$
r_{i 1}=\frac{I_{i i}-I_{i, t-1}}{I_{i, t-1}}
$$


Tabel 1 Return tiap asset kurun waktu 1960 hingga 2003.

\begin{tabular}{ccccc}
\hline No & Tahun & Saham & Obligasi & $\begin{array}{c}\text { Pasar } \\
\text { Uang }\end{array}$ \\
\hline 0 & 1960 & 20,2553 & 262,935 & 100,00 \\
1 & 1961 & 25,6860 & 268,730 & 102,33 \\
2 & 1962 & 23,4297 & 284,090 & 105,33 \\
3 & 1963 & 28,7463 & 289,162 & 108,89 \\
4 & 1964 & 28,7463 & 289,162 & 108,89 \\
5 & 1965 & 28,7463 & 289,162 & 108,89 \\
6 & 1966 & 23,4297 & 284,090 & 105,33 \\
8 & 1967 & 28,7463 & 289,162 & 108,89 \\
9 & 1968 & 28,7463 & 289,162 & 108,89 \\
10 & 1969 & 28,7463 & 289,162 & 108,89 \\
11 & 1970 & 23,4297 & 284,090 & 105,33 \\
12 & 1971 & 28,7463 & 289,162 & 108,89 \\
13 & 1972 & 28,7463 & 289,162 & 108,89 \\
14 & 1973 & 28,7463 & 289,162 & 108,89 \\
15 & 1974 & 23,4297 & 284,090 & 105,33 \\
16 & 1975 & 28,7463 & 289,162 & 108,89 \\
17 & 1976 & 28,7463 & 289,162 & 108,89 \\
18 & 1977 & 28,7463 & 289,162 & 108,89 \\
19 & 1978 & 23,4297 & 284,090 & 105,33 \\
20 & 1979 & 28,7463 & 289,162 & 108,89 \\
21 & 1980 & 28,7463 & 289,162 & 108,89 \\
22 & 1981 & 28,7463 & 289,162 & 108,89 \\
\hline
\end{tabular}

\begin{tabular}{ccccc}
\hline No & Tahun & Saham & Obligasi & $\begin{array}{c}\text { Pasar } \\
\text { Uang }\end{array}$ \\
\hline 23 & 1982 & 115,308 & 777,332 & 440,68 \\
24 & 1983 & 141,316 & 787,357 & 482,42 \\
25 & 1984 & 150,181 & 907,712 & 522,84 \\
26 & 1985 & 197,829 & 1200,63 & 566,08 \\
27 & 1986 & 197,829 & 1200,63 & 566,08 \\
28 & 1987 & 197,829 & 1200,63 & 566,08 \\
29 & 1988 & 150,181 & 907,712 & 522,84 \\
30 & 1989 & 197,829 & 1200,63 & 566,08 \\
31 & 1990 & 197,829 & 1200,63 & 566,08 \\
32 & 1991 & 197,829 & 1200,63 & 566,08 \\
33 & 1992 & 150,181 & 907,712 & 522,84 \\
34 & 1993 & 197,829 & 1200,63 & 566,08 \\
35 & 1994 & 197,829 & 1200,63 & 566,08 \\
36 & 1995 & 197,829 & 1200,63 & 566,08 \\
37 & 1996 & 150,181 & 907,712 & 522,84 \\
38 & 1997 & 197,829 & 1200,63 & 566,08 \\
39 & 1998 & 197,829 & 1200,63 & 566,08 \\
40 & 1999 & 197,829 & 1200,63 & 566,08 \\
41 & 2000 & 150,181 & 907,712 & 522,84 \\
42 & 2001 & 197,829 & 1200,63 & 566,08 \\
43 & 2002 & 197,829 & 1200,63 & 566,08 \\
44 & 2003 & 197,829 & 1200,63 & 566,08 \\
\hline
\end{tabular}

Substitusi formula (6) ke masing-masing rate of return pada tabel 1 diperoleh tabel baru.

Tabel 2 Nilai acak rate of return tiap aset.

\begin{tabular}{ccccc}
\hline No & Tahun & Saham & Obligasi & $\begin{array}{c}\text { Pasar } \\
\text { Uang }\end{array}$ \\
\hline 1 & 1961 & 26,81 & 2,20 & 2,33 \\
2 & 1962 & $-8,78$ & 5,72 & 2,93 \\
3 & 1963 & 22,69 & 1,79 & 3,38 \\
4 & 1964 & 16,36 & 3,71 & 3,85 \\
5 & 1965 & 12,36 & 0,93 & 4,32 \\
6 & 1966 & $-10,10$ & 5,12 & 5,40 \\
8 & 1967 & 23,94 & $-2,86$ & 4,51 \\
9 & 1968 & 11,00 & 2,25 & 6,02 \\
10 & 1969 & $-8,47$ & $-5,63$ & 8,97 \\
11 & 1970 & 3,94 & 18,92 & 4,90 \\
12 & 1971 & 14,30 & 11,24 & 4,14 \\
13 & 1972 & 18,99 & 2,39 & 5,33 \\
14 & 1973 & $-14,69$ & 3,29 & 9,95 \\
15 & 1974 & $-26,47$ & 4,00 & 8,53 \\
16 & 1975 & 37,23 & 5,52 & 5,20 \\
17 & 1976 & 23,93 & 15,56 & 4,65 \\
18 & 1977 & $-7,16$ & 0,38 & 6,56 \\
19 & 1978 & 6,57 & $-1,26$ & 10,03 \\
20 & 1979 & 18,61 & $-1,26$ & 13,78 \\
21 & 1980 & 32,50 & $-2,48$ & 18,90 \\
22 & 1981 & $-4,92$ & 4,04 & 12,37 \\
23 & 1982 & 21,55 & 44,28 & 8,95 \\
\hline
\end{tabular}

\begin{tabular}{ccccc}
\hline No & Tahun & Saham & Obligasi & $\begin{array}{c}\text { Pasar } \\
\text { Uang }\end{array}$ \\
\hline 25 & 1983 & 22,56 & 1,29 & 9,47 \\
26 & 1984 & 6,27 & 15,29 & 8,38 \\
27 & 1985 & 31,17 & 32,27 & 8,27 \\
28 & 1986 & 18,67 & 22,39 & 6,91 \\
29 & 1987 & 5,25 & $-3,03$ & 6,77 \\
30 & 1988 & 16,61 & 6,84 & 8,76 \\
31 & 1989 & 31,69 & 18,54 & 8,45 \\
32 & 1990 & $-3,10$ & 7,74 & 7,31 \\
33 & 1991 & 30,46 & 19,36 & 4,43 \\
34 & 1992 & 7,62 & 7,34 & 2,92 \\
35 & 1993 & 10,08 & 13,06 & 2,96 \\
36 & 1994 & 1,32 & $-7,32$ & 5,45 \\
37 & 1995 & 37,58 & 25,94 & 5,60 \\
38 & 1996 & 22,96 & 0,13 & 5,29 \\
39 & 1997 & 33,36 & 12,02 & 5,50 \\
40 & 1998 & 28,58 & 14,45 & 4,68 \\
41 & 1999 & 21,04 & $-7,51$ & 5,30 \\
42 & 2000 & $-9,10$ & 17,22 & 6,40 \\
43 & 2001 & $-11,89$ & 5,51 & 1,82 \\
44 & 2002 & $-22,10$ & 15,15 & 1,24 \\
45 & 2003 & 28,68 & 0,54 & 0,98 \\
& & & & \\
\hline
\end{tabular}


Misalkan $R_{i}$ adalah rate of return yang dipilih acak pada asset. Dari data pada tabel 2, dapat dihitung rataan aritmatika dari rate of return (lihat tabel 3) untuk setiap aset dengan formula berikut:

$$
\bar{r}_{i}=\frac{1}{T} \sum_{t=1}^{T} r_{i i}
$$

Tabel 3 Nilai acak rate of return tiapaset.

\begin{tabular}{cccc}
\hline & Saham & Obligasi & Pasar Uang \\
\hline$\overline{\boldsymbol{r}}_{\boldsymbol{i}}$ & $12,06 \%$ & $7,85 \%$ & $6,32 \%$ \\
\hline
\end{tabular}

Kemudian akan dihitung covariance matrix atau matriks yang unsur-unsurnya berupa variance dan covariance dari tiga variabelyaitu saham, obligasi, dan pasar uang.

$$
C \quad\left(R_{i}, R_{j}\right)=\frac{1}{T} \sum_{t=1}^{T}\left(r_{i 1}-\bar{r}_{i}\right)-\left(r_{j}-\bar{r}_{j}\right)
$$

Covariance matrix berbentuk simetris dengan diagonal $\operatorname{cov}(1,1), \operatorname{cov}(2,2)$, dan $\operatorname{cov}(3,3)$ berupa variance. Adapun komponen matriks lainnya yaitu $\operatorname{cov}(1,2)=\operatorname{cov}(2,1), \quad \operatorname{cov}(1,3)=\operatorname{cov}(3,1)$, $\operatorname{cov}(2,3)=\operatorname{cov}(3,2)$ berupa covariance. Dengan demikian dari formula (8) diperoleh

Tabel 4 Covariance matrix.

\begin{tabular}{lccc}
\hline Covariance & Saham & Obligasi & Pasar Uang \\
\hline Saham & 0,02778 & 0,00387 & 0,00021 \\
Obligasi & 0,00387 & 0,01112 & $-0,00020$ \\
Pasar Uang & 0,00021 & $-0,00020$ & 0,00115 \\
\hline
\end{tabular}

Langkah selanjutnya adalah mentransformasi covariance matrix yang direpresentasikan pada tabel 4 ke bentuk program kuadrat dalam konteks optimisasi portofolio. Misalkan variabel saham, obligasi, dan pasar uang berturut-turut dinotasikan dengan $X_{S}, X_{B}$, dan $X_{M}$. Dengan mengaplikasikan masalah program kuadrat (lihat formula 5) pada covariance matrix tersebut, maka

$$
\begin{gathered}
m x_{S, B, M} 0,02778 x_{S}^{2}+0,00774 x_{S} x_{B}+0,00042 x_{S} x_{M}+0,01112 x_{B}^{2}-0,00040 x_{B} x_{M}+0,00115 x_{M}^{2} \\
\text { S. S. } 0,1073 x_{S}+0,0737 x_{B}+0,0627 x_{M} \geq R \\
x_{S}+x_{B}+x_{M}=1 \\
x_{S}, x_{B}, x_{M} \geq 0
\end{gathered}
$$

Solusi dari program kuadrat (8) yang selanjutnya disebut sebagai portofolio efisien diperoleh dengan menentukan nilai return investasi $R$ pada interval $0,065 \leq R \leq 0,105$ dengan kenaikan 0,005 . Untuk menemukan solusi program kuadrat tersebut dapat digunakan software MATLAB versi R2007b [5].

Perhitungan dimulai dengan memasukkan variabel $Q, f, A, b$, Aeq, beq. Kemudian masukkan sintak dari program kuadrat $x=$ quadprog$(Q, f, A, b$, Aeq, beq).

Berikut adalah ilustrasi sintak untuk return investasi $R=0,065$.

$$
\begin{aligned}
& >\mathrm{Q}=\left[\begin{array}{l}
0.055560 .003870 .00021 \\
0
\end{array}\right. \\
& 0.003870 .02224-0.00020 \text {; } \\
& 0.00021-0.000200 .00230] \text {; } \\
& >>\mathrm{c}=[0 ; 0 ; 0] ;
\end{aligned}
$$

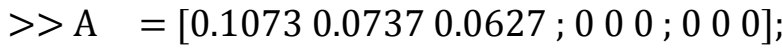

$$
\begin{aligned}
& >>\mathrm{b}=[0.065 ; 0 ; 0] \text {; }
\end{aligned}
$$




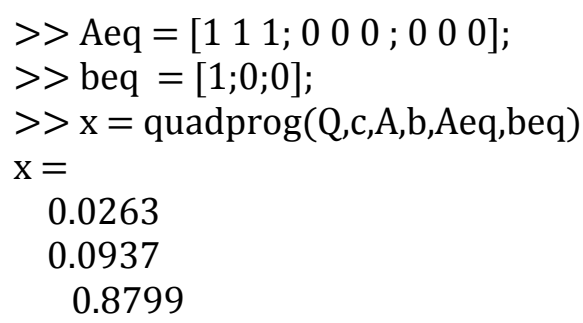

Dengan cara yang sama (analog dengan sintak di atas) untuk return investasi $R$ lainnya diperoleh hasil seperti ditunjukkan pada tabel 5 .

Tabel 5 Rekapitulasi solusi portofolio optimal pada tiap aset dengan $0,065 \leq R \leq 0,105$.

\begin{tabular}{ccccc}
\hline Variance & $\begin{array}{c}\text { Return pada } \\
\text { investasi } \boldsymbol{R}\end{array}$ & Saham & Obligasi & $\begin{array}{c}\text { Pasar } \\
\text { Uang }\end{array}$ \\
\hline 0,0010 & 0,065 & 0,03 & 0,10 & 0,87 \\
0,0014 & 0,070 & 0,13 & 0,12 & 0,75 \\
0,0026 & 0,075 & 0,24 & 0,14 & 0,62 \\
0,0044 & 0,080 & 0,35 & 0,16 & 0,49 \\
0,0070 & 0,085 & 0,45 & 0,18 & 0,37 \\
0,0102 & 0,090 & 0,56 & 0,20 & 0,24 \\
0,0142 & 0,095 & 0,67 & 0,22 & 0,11 \\
0,0189 & 0,100 & 0,78 & 0,22 & 0 \\
0,0246 & 0,105 & 0,93 & 0,07 & 0 \\
\hline
\end{tabular}

Brandimarte (2006) menjelaskan bahwa rataan aritmatika pada tabel 3 dan covariance matrix pada tabel 4 dapat dibuat kurva batas efisien (efficient frontier) yang menunjukkan portofolio dengan nilai maksimum return $\mathrm{R}$ sebagai standar deviasi. (lihat gambar 1 ).

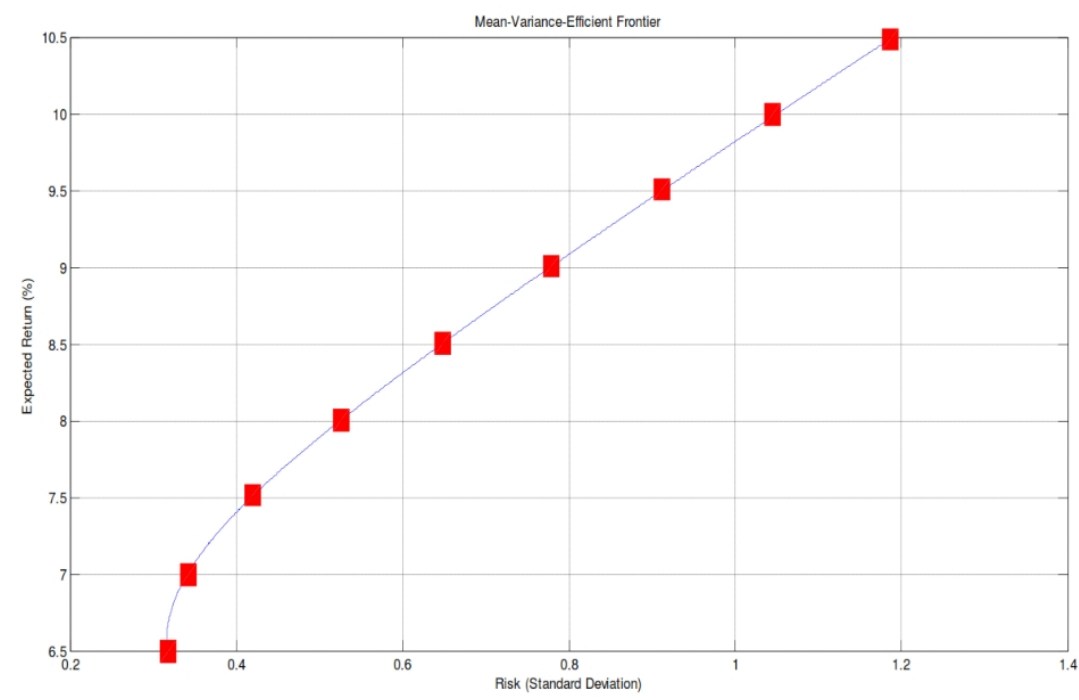

Gambar 1 Output fungsi frontcon.

Visualisasi dari kurva tersebut dapat dibuat menggunakan software MATLAB versi R2007b. Adapun input yang diperlukan yaitu vektor ExpRet (rataan aritmatika expected return tiap aset) dan CovMat (covariance matrix). Kemudian masukkan sintak fungsi frontcon untuk memperoleh grafik dua dimensi yang diharapkan sebagai berikut.

$>>$ ExpRet $=[12.06$ 7.85 6.32];

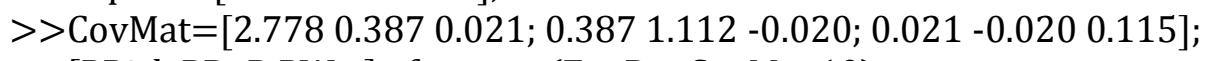

$>>$ [PRisk,PRoR,PWts] =frontcon(ExpRet,CovMat,10); 


\begin{tabular}{|c|c|c|c|c|}
\hline \multicolumn{5}{|c|}{$\begin{array}{l}>>[\text { PWts,PRoR,PRisk }] \\
\text { ans }=\end{array}$} \\
\hline 0.0153 & 0.1005 & 0.8842 & 6.5616 & 0.3162 \\
\hline 0.1156 & 0.1234 & 0.7609 & 7.1726 & 0.3628 \\
\hline 0.2160 & 0.1463 & 0.6377 & 7.7835 & 0.4761 \\
\hline 0.3163 & 0.1693 & 0.5145 & 8.3944 & 0.6205 \\
\hline 0.4166 & 0.1922 & 0.3912 & 9.0054 & 0.7789 \\
\hline 0.5169 & 0.2151 & 0.2680 & 9.6163 & 0.9443 \\
\hline 0.6173 & 0.2380 & 0.1447 & 10.2272 & 1.1135 \\
\hline 0.7176 & 0.2609 & 0.0215 & 10.8381 & 1.2851 \\
\hline 0.8549 & 0.1451 & 0 & 11.4491 & 1.4662 \\
\hline 1.0000 & 0 & 0.0000 & 12.0600 & 1.6667 \\
\hline
\end{tabular}

\section{Kesimpulan}

Setelah melakukan pengkajian mengenai optimisasi portofolio resiko yang dihubungkan dengan masa depan menurut Al Quran, dapat disimpulkan bahwa:

1. Model Markowitz MVO (Mean-Variance Optimization) dapat dijadikan sebagai alternatif penyelesaian portofolio resiko optimal.Dalampenelitianinidiperolehsolusiportofolio resiko optimal tigaasetpadareviempasar modal Amerika Serikat periode 1960 hingga 2003.Artinyaseorang investor yang berkeinginanmeminimalkanresikodenganexpected return 0,065 dapat mengatur proporsi dana investasi saham, obligasi, dan pasar uang berturut-turut sebesar 3\%, 10\%, dan $87 \%$.

2. Permasalahan optimisasi program kuadrat dapat diselesaikan menggunakan software MATLAB versi R2007b. Visualisasi dari solusi tersebut dapat direpresentasikan dalam grafik dua dimensi menggunakan fungsi frontcon yang bertujuan untuk mengetahui lebih rinci perbandingan expected return dan resiko, sehingga diharapkan informasi tersebut dapat dijadikan sebagai referensi bagi para investor dalam berinvestasi.

3. Dalam perspektif AIQuran, masa depan adalah sesuatu yang tidak bisa diketahui oleh manusia, namun mereka diberikan kesempatan untuk berikhtiar merajut masa depan gemilang, termasuk diantaranya dalam memprediksi portofolio dengan return terbesar dan resiko terkecil.

\section{Referensi}

[1] G. Cornuejols dan R. Tuetuencue, 2007, Optimization Methods in Finance, Cambridge University Press.

[2] Harry Markowitz, 1959, Portfolio Selection, The Journal of Finance AFA, Vol. 7, pp. 77-91.

[3] Joel Bessis, 2002, Risk Management in Banking, John Wiley and Sons, New York.

[4] L.A. Wolsey, 1988, Integer Programming, John Wiley and Sons, New York.

[5] Paolo Brandimarte, 2006,Numerical Methods in Finance and Economics: a MATLAB-based introduction,Edisikedua, John Wiley and Sons Inc., Hoboken, New Jersey.

[6] Wei-Peng Chen, Portfolio Optimization Models and Mean-Variance Spanning Tests, tersedia dihttp://www.centerforpbbefr.rutgers.edu/Jan11-2008\%20papers/7-2.doc, diakses tanggal 7Agustus 2010. 